\title{
The JEVIN trial: A population-based survey on the quality of diabetes care in Germany: 1994/1995 compared to 1989/1990
}

\author{
R.Schiel ${ }^{1}$, U. A.Müller ${ }^{1}$, H.Sprott ${ }^{1}$, A.Schmelzer ${ }^{1}$, B.Mertes ${ }^{1}$, W.Hunger-Dathe ${ }^{1}$, I.S. Ross ${ }^{2}$ \\ ${ }^{1}$ University of Jena Medical School, Department of Internal Medicine II, Jena, Germany \\ ${ }^{2}$ University of Aberdeen Medical School, Department of Clinical Biochemistry, Aberdeen, UK
}

Summary Since 1990 in most Eastern European countries health care systems have been decentralized or are undergoing the processes of decentralization. Increasingly, diabetic patients are no longer treated by diabetologists but by non-specialized physicians. During the same period structured treatment and teaching programmes have been introduced and health care is increasingly influenced by the St. Vincent declaration. To show the effect of these changes on the quality of diabetes care $90 \%(n=244)$ of all insulin-treated diabetic patients aged 16 to 60 years and living in the city of Jena (100247 inhabitants) were studied in 1994/1995. The results were compared with the baseline examination of $1989 / 1990$ $(n=190)$. $\mathrm{HbA}_{1 \mathrm{c}}\left(\mathrm{HbA}_{1 \mathrm{c}} /\right.$ mean normal) in IDDM patients under specialized care was similar in 1994/1995 $(1.54 \pm 0.27, \quad n=47)$ to $1989 / 1990 \quad(1.52 \pm 0.31$, $n=131, p=0.0018)$, but higher under non-specia- lized care $(1.71 \pm 0.38, n=80, p=0.0087)$. In the total group of NIDDM patients there was no significant change in $\mathrm{HbA}_{1 \mathrm{c}}(1994 / 1995: 1.75 \pm 0.4, n=117$, vs 1989/1990: $1.78 \pm 0.4, n=59, p=0.67)$, but with a tendency to higher $\mathrm{HbA}_{1 \mathrm{c}}$ under non-specialized $(1.81 \pm 0.4, n=79)$ compared to specialized care $(1.66 \pm 0.39, n=38, p=0.06)$. Incidence of severe hypoglycaemia (IDDM 0.13; NIDDM 0.04), ketoacidosis $(0.02 ; 0.01)$ and the prevalence of nephropathy $(21 \% ; 35 \%)$ and neuropathy $(24 \% ; 38 \%)$ remained unchanged in comparison to $1989 / 1990$, whereas there was an increase in the prevalence of diabetic retinopathy. Specialized care is mandatory for patients with IDDM. [Diabetologia (1997) 40: 1350-1357]

Keywords IDDM, NIDDM, population-based trial, $\mathrm{HbA}_{1 \mathrm{c}}$, care quality.
Insulin-dependent (IDDM) and non-insulin-dependent (NIDDM) diabetes mellitus confer a high risk of developing diabetic late complications with the result of excess mortality and morbidity [1-5]. Up to the present, optimal quality of care and regular screening have been the most important factors for preventing late complications [6-10]. Most of the data available concerning quality management of diabetes have been derived from selected populations $[11,12]$.

Received: 3 April 1997 and in revised form: 18 June 1997

Corresponding author: R.Schiel, M.D., University of Jena Medical School, Department of Internal Medicine II, D07740 Jena, Germany

Abbreviations: NIDDM, Non-insulin-dependent diabetes mellitus; IDDM, insulin-dependent diabetes mellitus; 5-DTTP, 5 -day diabetes treatment and teaching programme.
The purpose of this trial was to prove the implementation of the St. Vincent Declaration [13] in a non-selected population of diabetic patients in Germany with respect to the change in the health care from a centralized state system to a private one.

\section{Subjects and methods}

The JEVIN Trial (Jena's St. Vincent Trial), was started in 1989 in Jena (population in 1989: 105825), a town in the former German Democratic Republic [14]. The centralized diabetes care system was at that time intact. It was based on nationwide country and district diabetes care units and a diabetes registry [15]. At 31 December 1989 there were 3923 patients registered in Jena [14]. We examined $83 \%(n=190)$ of the 229 registered insulin-treated patients in the age group of 16 to 60 years [14, 16]. 
Table 1. Characteristics of the patients examined in $1989 / 1990$ in comparison to $1994 / 1995$

\begin{tabular}{|c|c|c|c|c|c|c|}
\hline & \multicolumn{3}{|l|}{ IDDM } & \multicolumn{3}{|l|}{ NIDDM } \\
\hline & $1989 / 1990$ & $1994 / 1995$ & $p$ value & $1989 / 1990$ & $1994 / 1995$ & $p$ value \\
\hline $\begin{array}{l}\text { No. of patients } \\
\text { Age (years) } \\
\text { Females (\%) }\end{array}$ & $\begin{array}{l}131 \\
37.0 \pm 11.6 \\
39\end{array}$ & $\begin{array}{l}127 \\
40.1 \pm 12.0 \\
36\end{array}$ & $\begin{array}{l}0.064 \\
0.879\end{array}$ & $\begin{array}{l}59 \\
53.0 \pm 5.3 \\
59\end{array}$ & $\begin{array}{l}117 \\
52.8 \pm 6.4 \\
54\end{array}$ & $\begin{array}{l}0.581 \\
0.568\end{array}$ \\
\hline $\begin{array}{l}\text { Diabetes duration (years) } \\
\text { Body mass index }\left(\mathrm{kg} / \mathrm{m}^{2}\right) \\
\text { Current smokers }(\%) \\
\text { Invalidity }(\%)\end{array}$ & $\begin{array}{l}14.4 \pm 11.0 \\
23.5 \pm 2.7 \\
43 \\
14\end{array}$ & $\begin{array}{l}16.8 \pm 12.1 \\
24.2 \pm 3.2 \\
32 \\
19\end{array}$ & $\begin{array}{l}0.091 \\
0.013 \\
0.0005 \\
0.434\end{array}$ & $\begin{array}{l}13.4 \pm 4.8 \\
28.5 \pm 4.8 \\
32 \\
11\end{array}$ & $\begin{array}{l}12.3 \pm 7.3 \\
28.6 \pm 4.6 \\
24 \\
25\end{array}$ & $\begin{array}{l}0.307 \\
0.865 \\
<0.0001 \\
0.014\end{array}$ \\
\hline $\begin{array}{l}\text { Systolic blood pressure (mm Hg) } \\
\text { Diastolic blood pressure (mm Hg) } \\
\text { Antihypertensive treatment (\%) } \\
\text { Real hypertension }{ }^{\text {a }}(\%)\end{array}$ & $\begin{array}{l}135 \pm 18 \\
85 \pm 9 \\
20 \\
31\end{array}$ & $\begin{array}{l}129 \pm 16 \\
79 \pm 9 \\
25 \\
31\end{array}$ & $\begin{array}{l}0.0039 \\
<0.0001 \\
0.393 \\
0.962\end{array}$ & $\begin{array}{l}151 \pm 28 \\
91 \pm 13 \\
53 \\
69\end{array}$ & $\begin{array}{l}137 \pm 19 \\
82 \pm 10 \\
47 \\
55\end{array}$ & $\begin{array}{l}0.0003 \\
<0.0001 \\
0.569 \\
0.051\end{array}$ \\
\hline
\end{tabular}

Mean normal $\mathrm{HbA}_{1 \mathrm{c}}$ in 1989/1990 4.15\% (SD 0.54), in 1994/1995 5.1 (SD 0.38). ${ }^{a} \mathrm{BP} \geq 160 \mathrm{~mm} \mathrm{Hg}$ systolic and/or $\geq 95 \mathrm{~mm} \mathrm{Hg}$ diastolic and/or antihypertensive treatment

Since 1990, following the reunification of Germany, the health care system has been decentralized. Diabetes care units were mostly closed and diabetic patients were increasingly treated by non-specialized physicians. The central diabetes registry was discontinued. Ambulatory and inpatient care is sharply demarcated, with specialized physicians restricted from admitting patients without assignment of primary care physicians. Hospital care physicians are largely proscribed from providing outpatient care [17].

We identified the patients for the 5-year follow-up trial in 1994/1995 from four independent sources: 1) the previous diabetes registry from 1989;2) the hospital database, because up to 1995 in Thuringia insulin treatment had only been started in hospitals; 3) the database of the university clinic outpatient department and 4) databases of family physicians. This method of using several sources guarantees $100 \%$ identification of the target population by tracking each patient in at least two different sources.

Patients. In 1994/1995, we identified 271 insulin-treated diabetic patients aged 16 to 60 years and living in the city of Jena (population in 1995: 100242). Of these patients (IDDM $n=127$, NIDDM $n=117$, [18]) $90 \%$ were examined by a physician. Since 199017 insulin-treated registered patients had died. Of the missing 27 patients, 10 refused to take part (3.7\%) and of the rest $(n=16,6.3 \%)$ we were either unable to trace the address or patients did not reply. The characteristics of the patients examined in 1994/1995 in comparison to $1989 / 1990$ are shown in Table 1.

Intervention since 1989/1990. Following the reunification of Germany, with the change of the political system, there have been great shifts in socioeconomic factors. For example materials for blood glucose self-monitoring and insulin pens became available to everyone at all times. Additionally, the 'diabetic diet' $[19,20]$ has been liberalized [21].

Following the recommendations of the St. Vincent Declaration [13], structured treatment programmes for both IDDM and NIDDM were established [22-29]. Since 1989/1990 73\% of IDDM $(n=93)$ and $34 \%$ of NIDDM patients $(n=40)$ have taken part in a 5-day structured diabetes treatment and teaching programme (5-DTTP) for intensified conventional insulin therapy [22]. Of the NIDDM patients $63 \%(n=74)$ have taken part in a 5-DTTP for type 2 diabetic patients with insulin therapy [23]. A total of $9 \%(n=10)$ of NIDDM patients took part in both 5-DTTPs $[22,23]$. Only $27 \%(n=34)$ of IDDM patients and $11 \%(n=13)$ of NIDDM patients have not taken part in a DTTP up to the present. Until 1993, in the area of Jena, $56 \%$ of general practitioners and physicians for internal medicine [16] took part in postgraduate training courses for the treatment of NIDDM.

Assessment of quality of care. To assess the quality of care the following investigations were performed: measurement of haemoglobin $\mathrm{A}_{1 \mathrm{c}}\left(\mathrm{HbA}_{1 \mathrm{c}}\right.$, HPLC, Diamat, normal range: 4.4$5.9 \%$ in $1994 / 1995,3.1-5.2 \%$ in $1989 / 1990$, laboratory tests in $1989 / 1990$ were performed in Aberdeen, the normal range of each method was assessed measuring 100 healthy subjects). For comparison of the two $\mathrm{HbA}_{1 \mathrm{c}}$ methods values were normed on the mean normal value (original $\mathrm{HbA}_{\mathrm{lc}}$ value divided by the mean normal of the method), a method which guarantees good reliability as shown in the German Working Group for structured diabetes care. Self-monitoring and insulin dose adjustment were registered as frequency of tests/adjustments per week. The incidence of acute complications (severe hypoglycaemia, i.e. need for glucose or glucagon injection, ketoacidosis with hospitalization) were assessed by interview and controlled by comparison with emergency protocols and hospital records. Investigation of long-term diabetic complications was done by: 1) funduscopy through dilated pupils by an ophthalmologist. Retinopathy was staged as follows: normal, stage 1 (microaneurysms or soft exudates only), stage 2 (blot haemorrhages, hard exudates), stage 3 (proliferation and vitreous haemorrhages) [30]. 2) Screening for peripheral polyneuropathy according to Young et al. [4]. 3) Screening for nephropathy by measuring the urine albumin concentration (immunoturbidimetry 1989/1990, nephelometry 1994/1995, normal range: $<20 \mathrm{mg} / \mathrm{l}$ ). For calculation the mean of three early morning urine tests within a period of 3 to 6 weeks was used. In the case of only two specimens being available the results were used only if both were in the normal range or both were elevated. Infected urine specimens (bacterial counts $>10^{5} / \mathrm{ml}$ ) were excluded.

Height and body weight were assessed with the patients wearing light clothing and without shoes. Blood pressure in the sitting position was measured after the patient had rested for $10 \mathrm{~min}$ by using a standard sphygmomanometer according to World Health Organisation (WHO) recommendations. Further socioeconomic data, quality of life and treatment satisfaction were assessed, and will be published in a forthcoming paper.

Statistical analysis was performed using Statgraph. All data are presented as mean \pm SD. For comparisons the Student's $t$-test, 
Table 2. Characteristics and results of diabetes therapy

\begin{tabular}{|c|c|c|c|c|c|c|}
\hline & \multicolumn{3}{|l|}{ IDDM } & \multicolumn{3}{|l|}{ NIDDM } \\
\hline & $1989 / 1990$ & $1994 / 1995$ & $p$ value & $1989 / 1990$ & $1994 / 1995$ & $p$ value \\
\hline No. of patients & 131 & 127 & & 59 & 117 & \\
\hline $\begin{array}{l}\text { Self-monitoring } \\
\text { Blood glucose }(n / \text { week }) \\
\text { Urine glucose }(n / \text { week })\end{array}$ & $\begin{array}{l}2.5 \pm 6.2 \\
2.9 \pm 5.6\end{array}$ & $\begin{array}{c}21.1 \pm 11.5 \\
0.8 \pm 3.1\end{array}$ & $\begin{array}{l}<0.0001 \\
0.0002\end{array}$ & $\begin{array}{l}1.0 \pm 3.9 \\
2.1 \pm 4.3\end{array}$ & $\begin{array}{c}14.9 \pm 10.7 \\
1.5 \pm 3.9\end{array}$ & $\begin{array}{l}<0.0001 \\
0.376\end{array}$ \\
\hline
\end{tabular}

${ }^{\mathrm{a}}$ Mean normal HbA ${ }_{1 \mathrm{c}}$ in $1989 / 19904.15 \%$ (SD 0.54); ${ }^{\mathrm{b}}$ in $1994 / 19955.1 \%$ (SD 0.38)

chi-square test, Fisher's exact test for frequencies at or below 5 and Wilcoxon's rank sum test were used. Significance was defined at the 0.05 level.

\section{Results}

In 1994/1995 according to WHO criteria [18] 127 patients $(52.0 \%)$ suffered from IDDM and 117 patients (47.9\%) from NIDDM. Patients' treatment data and data on quality of diabetes care for the populations $1994 / 1995$ compared to $1989 / 1990$ are summarized in Table 2.

Quality of diabetes care. For the total group of IDDM patients examined, the $\mathrm{HbA}_{1 \mathrm{c}}\left(\mathrm{HbA}_{1 \mathrm{c}} /\right.$ mean normal) increased from $1989 / 1990(1.52 \pm 0.31)$ compared to $1994 / 1995(1.65 \pm 0.35, p=0.0018)$. The $\mathrm{HbA}_{1 \mathrm{c}}$ of patients under specialized care in 1994/1995 was similar $(1.54 \pm 0.27, n=47)$ to patients in $1989 / 1990$ $(1.52 \pm 0.31, n=131, p=0.0018)$ and significantly better than that for patients treated by non-specialized physicians in 1994/1995 (1.71 $\pm 0.38, n=80$, $p=0.0087$ ). In NIDDM the $\mathrm{HbA}_{1 \mathrm{c}}$ was similar in $1994 / 1995\left(1.75 \pm 0.4 \mathrm{HbA}_{1 \mathrm{c}} /\right.$ mean, $\left.n=117\right)$ compared to $1989 / 1990(1.78 \pm 0.4, n=59, p=0.67)$. There were no differences between the groups as regards education, profession, unemployment or other socioeconomic factors.

There was a marked increase in the number of insulin injections and the frequency of self-monitoring in 1994/1995 compared to 1989/1990. Regular blood glucose self-monitoring (i.e. at least one test per week) was performed by $93 \%$ of IDDM $(22.7 \pm 10.2$ tests/week) and $87 \%$ of NIDDM patients (17.2 \pm 9.8 tests/week), in contrast to only $56 \%$ of IDDM $(4.5 \pm 7.8$ tests/week) and $24 \%$ of NIDDM patients (4.4 \pm 7.3 tests/week) in 1989/1990. The number of insulin injections per day increased significantly in

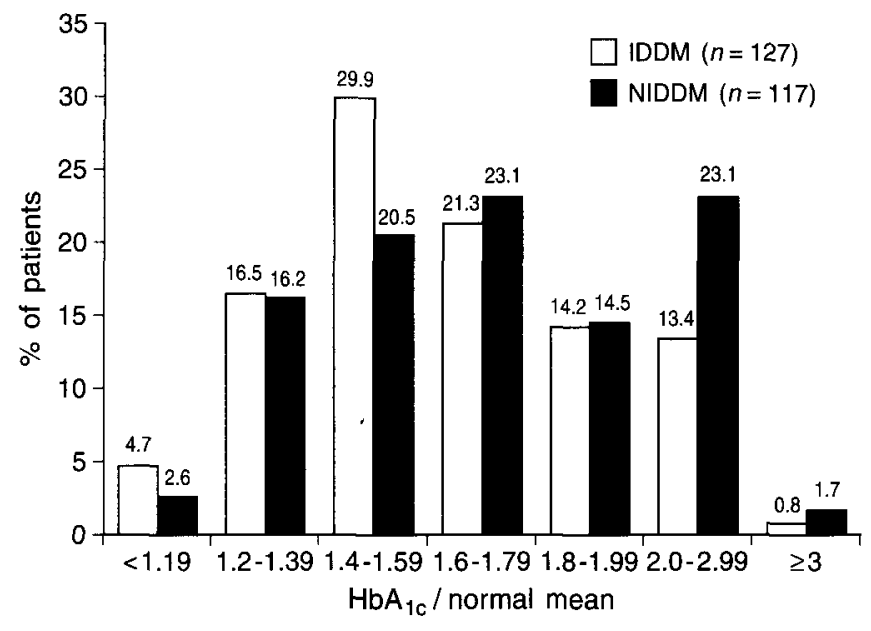

Fig. 1. Distribution of $\mathrm{HbA}_{1 \mathrm{c}}$ normal mean in IDDM and NIDDM patients in 1994/1995

IDDM and NIDDM patients. Eighty-five percent $(n=108)$ of IDDM and $48 \%(n=56)$ of NIDDM patients performed insulin therapy with short-acting and mixed/NPH-insulin with mostly 4 to 6 injections per day.

In IDDM patients there were no correlations between $\mathrm{HbA}_{1 \mathrm{c}}$ and age $(r=-0.04, p=0.66)$, diabetes duration $(r=0.07, p=0.47)$, insulin dosage $/ \mathrm{kg}$ body weight $(r=0.18, p=0.07)$ or the number of insulin injections/day $(r=0.09, p=0.33)$. But we found a positive correlation between systolic blood pressure and $\mathrm{HbA}_{1 \mathrm{c}}(r=0.2, p=0.036)$ and a negative correlation between $\mathrm{HbA}_{1 \mathrm{c}}$ and body mass index $(r=-0.26$, $p=0.0062)$ and $\mathrm{HbA}_{1 \mathrm{c}}$ and participation in a 5DTTP for intensified conventional insulin therapy [22] $(r=-0.22, r=0.023)$.

Similar results were found for NIDDM patients: a negative correlation between $\mathrm{HbA}_{1 \mathrm{c}}$ and body mass index $(r=-0.34, p=0.0065)$ and $\mathrm{HbA}_{1 \mathrm{c}}$ and participation in a 5-DTTP for type 2 diabetic patients with 
Table 3. Incidence of acute diabetes complications (severe hypoglycaemia: glucagon i.v., glucagon-injection, ketoacidosis with hospitalization) 1989/1990 versus 1994/1995

\begin{tabular}{|c|c|c|c|c|c|c|}
\hline & \multicolumn{3}{|l|}{ IDDM } & \multicolumn{3}{|l|}{ NIDDM } \\
\hline & $1989 / 1990$ & $1994 / 1995$ & $p$ value & $1989 / 1990$ & $1994 / 1995$ & $p$ value \\
\hline $\begin{array}{l}\text { No. of patients (\%) } \\
\text { Severe hypoglycaemia }\end{array}$ & & & & & & \\
\hline Including pregnancy & $10(8 \%)$ & $16(12.6 \%)$ & 0.264 & $1(2 \%)$ & $5(4.3 \%)$ & 0.653 \\
\hline Ketoacidosis & $2(1.6 \%)$ & $2(1.6 \%)$ & 0.707 & 0 & $1(0.9 \%)$ & 0.726 \\
\hline
\end{tabular}

Table 4. Diabetes late complications in patients examined 1989/1990 versus 1994/1995

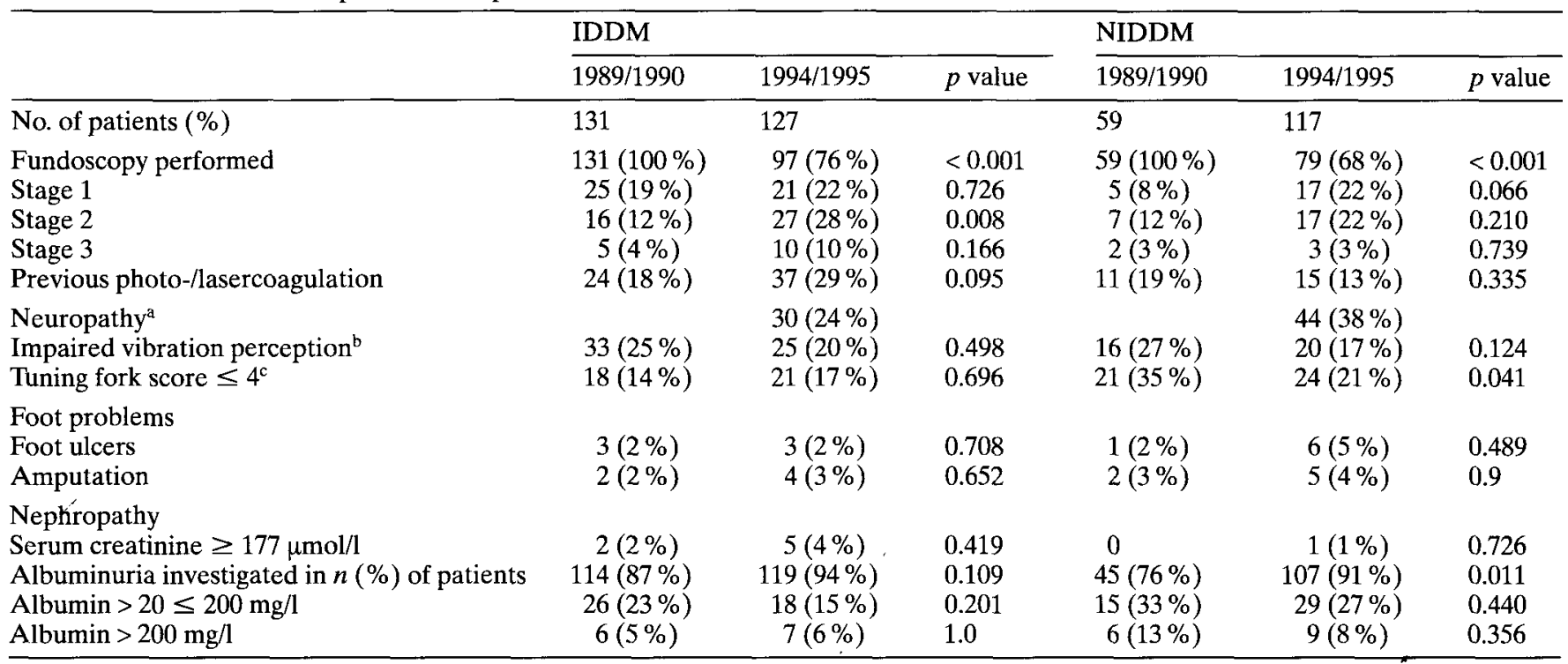

${ }^{a}$ According to Young et al. [4], ${ }^{b}$ abnormal age-related score according to Liniger et al. [30]; mean at both sides, ${ }^{\mathrm{c}}$ on at least one side

insulin therapy [23] and between the frequency of blood glucose monitoring $(r=-0.28, p=0.03)$.

Acute diabetic complications. The incidence of acute complications, severe hypoglycaemia and ketoacidosis, remained stable in 1989/1990 compared to 1994/ 1995 as shown in Table 3.

Retinopathy. In 1994/1995 funduscopy was performed in $76 \%$ of IDDM and in $68 \%$ of NIDDM patients. The prevalence of retinopathy increased in IDDM and NIDDM (Table 4). Blindness (visus < 0.02) was found in three patients in 1994/1995 (IDDM $n=1$, NIDDM $n=2$ ), whereas there was one blind patient identified in 1989/1990.

Neuropathy. According to the neuropathy disability and symptom score used for diagnosis of peripheral neuropathy [4] in 1994/1995 peripheral neuropathy was found in $24 \%$ of IDDM and $38 \%$ of NIDDM patients. The prevalence of impaired vibration perception (age-related score according to Liniger et al. [31] at the first metatarsal bone) remained unchanged (Table 4).
Nephropathy. There was no significant change in the prevalence of nephropathy, either in albuminuria or in serum creatinine (Table 4). In IDDM patients early renal failure was found in four patients after a mean duration of diabetes of $26.3 \pm 11.2$ (range $8-37$ ) years. Two patients had received a renal transplant.

In IDDM patients a positive correlation was found between albuminuria and duration of diabetes $(r=0.3, p=0.0015)$ and serum creatinine $(r=0.55$, $p<0.001)$ and between systolic blood pressure and albuminuria $(r=0.19, p=0.04)$. In NIDDM patients there was a positive correlation between albuminuria and serum creatinine $(r=0.26, p=0.04)$, but there were no correlations between age and duration of diabetes or blood pressure.

Smoking. The number of current smokers in IDDM patients decreased significantly from $43 \%$ in $1989 /$ 1990 to $32 \%$ in $1994 / 1995(p=0.0005)$ and in NIDDM from $32 \%$ to $24 \%(p<0.00001)$.

Multivariate analysis. Performing multivariate analysis for IDDM patients, the most important factor 
associated with $\mathrm{HbA}_{1 \mathrm{c}}(R$ squared 0.053$)$ was regular treatment by a diabetologist $(c=-0.17, p=0.009)$. All other parameters, investigated in the model (sex, age and duration of diabetes, BMI, frequency of insulin injections/day, frequency of self-monitoring, insulin dosage and educational level) had no statistically significant associations with $\mathrm{HbA}_{1 \mathrm{c}}$.

The most important parameters associated with $\mathrm{HbA}_{1 \mathrm{c}}$ in NIDDM patients ( $R$ squared 0.15 ) were the frequency of blood glucose self-tests/week $(c=-0.013, p=0.003)$ and the daily insulin dosage $(c=0.48, p=0.01)$. No associations were found for age, BMI, treatment by specialized physicians, diabetes duration, frequency of insulin injections, urine glucose self tests/week and educational level.

\section{Discussion}

Both IDDM and NIDDM are common diseases associated with reduced life expectancy and high mortality and morbidity $[1,2,32,33]$. The most important factors for preventing late complications are better quality of diabetes care with near normoglycaemia, and regular screening of patients $[6,7,10]$. However, to evaluate the efficacy of centralized diabetes care in 1989/1990 we chose a selection-free population of insulin-treated diabetic patients aged 16 to 60 years. Older patients were not studied because diabetes is only one facet of their multimorbidity. In these patients $\mathrm{HbA}_{1 \mathrm{c}}$ is not the primary parameter to estimate care quality. For these patients individualized treatment goals are crucially important. Younger patients are mostly in employment and the goal of the therapy is near normoglycaemia to prevent late complications [34].

In 1989/1990 under a centralized diabetes care system $[14,15,35,36]$ all diabetic patients were registered and regularly examined at regional diabetes care centres. Looking at $\mathrm{HbA}_{1 \mathrm{c}}$ in insulin-treated IDDM and NIDDM patients aged 16 to 60 years, quality of diabetes care appeared to have been successfully achieved. Regional diabetes care centres existed overall in the former GDR and everywhere patients were treated following the same guidelines. Although results from other East European countries showed very high $\mathrm{HbA}_{1 \mathrm{c}}$ levels before intervention [37] quality of diabetes care in Jena seems to be representative of the whole GDR [36]. But in 1994/ 1995 , at the time this follow-up trial was performed, this centralized diabetes care system no longer existed. Most patients are now treated by GPs, and about $19 \%$ by diabetologists [16]. Up to the present no data derived from non-selected populations have been available to measure influences of the shift from centralized to private health care systems. Based on the rationale that an accurate estimation of the diabetes prevalence can be assessed only by using more than one source for identification of diabetic patients [38, 39 ], in the present trial three independent sources were used to prevent a bias due to patient selection.

In IDDM patients under specialized care the $\mathrm{HbA}_{1 \mathrm{c}}$ was similar compared to the population studied in 1989/1990. But it was higher for IDDM patients treated by non-specialized physicians only. There was no positive selection of patients under specialized care regarding socioeconomic factors and the prevalence of late complications. In the multivariate analysis we found only one parameter independently associated with $\mathrm{HbA}_{1 \mathrm{c}}$ : care by a diabetologist.

In NIDDM patients we found no significant difference in $\mathrm{HbA}_{1 \mathrm{c}}$ in patients under specialized or nonspecialized care. But, more than half of general practitioners and physicians for internal medicine [16] took part in postgraduate training courses for NIDDM patients [40]. This may be one of the reasons for the stability of treatment quality in NIDDM patients. There was an impressive increase in regular blood glucose self-monitoring from 1989/1990 to $1994 / 1995$ in IDDM (from 56 to $93 \%$ ) and in NIDDM (from 24 to $87 \%$ ). However, in the multivariate analysis the frequency of blood glucose monitoring was the most independent factor associated with $\mathrm{HbA}_{1 \mathrm{c}}$ in insulin-treated NIDDM patients only. Perhaps this is a further reason why impairment of $\mathrm{HbA}_{1 \mathrm{c}}$ was prevented in NIDDM patients, whereas in older NIDDM patients no benefit of blood glucose self-monitoring has been reported [41]. Another issue concerns the question of whether insulin monotherapy is really superior to combination therapy with insulin and oral antidiabetic drugs. Regarding the disappearance of deterioration of $\mathrm{HbA}_{1 \mathrm{c}}$ after withdrawal of most of the sulfonylureas in the NIDDM population studied, this issue might be negotiated. In the UKPDS [8, 9], up to now no advantages of therapies with oral antidiabetic drugs have been seen. In numerous trials the efficacy of DTTP [22, 23, 29] for both IDDM and NIDDM patients, with or without insulin treatment, has been established. The quality of diabetes care improved, the incidence of acute complications and frequency and duration of patients' hospitalization could be reduced or were stable [24-27, 42-45]. Following these results, training and teaching in diabetes management and care for people of all ages with both IDDM and NIDDM and for their families was one of the central recommendations of the St. Vincent Declaration action programme, and also of other national and international guidelines for treatment of diabetic subjects $[18,28$, 46-49].

Although in several trials for selected patients, educated at our centre, significant improvement of quality of diabetes care after participation in 5DTTP was established $[26,27,50-52]$ no significant improvement in quality of diabetes care in the selection-free population of diabetic patients could be 
found. On the other hand, after the discontinuation of the centralized health care system, an impairment in quality of diabetes care was shown in IDDM patients without specialized care, but there was no increase in the incidence of ketoacidoses as was expected [53]. Together with the disappearance of the centralized diabetes care system there were great changes in individual lifestyles which may interact with patients' quality of diabetes care: for example need for more flexibility, the availability of different foods, new opportunities to travel and a higher unemployment rate.

The prevalence of neuropathy and microalbuminuria were similar to $1989 / 1990$ and have been reported by other groups [3-5, 54-59]. Fortunately the number of smokers decreased in our study, despite a tremendous increase in cigarette advertisements. Perhaps the lower frequency of smokers in 1994/1995 versus 1989/1990 in IDDM and NIDDM led to a reduction of overt nephropathy. Numerous trials clearly demonstrated that cigarette smoking appears to be a strong risk factor for the development and progression of nephropathy in diabetic patients $[60,61]$.

However, regarding retinopathy there was a significant increase in frequency in 1994/1995 compared to 1989/1990 in both IDDM and NIDDM, including a bias resulting from missing up to a quarter of eye examinations in 1994/1995. Concerning this tendency and the increase of $\mathrm{HbA}_{1 \mathrm{c}}$ in IDDM patients without specialized care, modifications of the present private health care system are mandatory to prevent inconvenient and costly treatment of diabetes complications in the future.

In particular regarding the changes in health care systems in other Eastern European countries, the results of the present non-selected, population-based trial are important. Models like the St. Vincent Declaration action programme or the WHO Partnerships for Health, aiming at the improvement of long-term outcome of patients and helping them to improve self-management, should be emphasized, but must be also critically monitored and evaluated. In all in- and outpatient centres for diabetes care it must be mandatory to take part in a regular system of quality assurance $[62,63]$ as shown by the Working Group of structured diabetes therapy of the German Diabetes Association [45]. However, only a prospective controlled trial could fully answer the question of whether IDDM patients who continue to look for specialized care will have a better outcome.

\section{References}

1. Panzram G, Zabel-Langhennig R (1981) Prognosis of diabetes mellitus in a geographically defined population. Diabetologia 20: $587-591$
2. Panzram G (1987) Mortality and survival in type 2 (non-insulin-dependent) diabetes mellitus. Diabetologia 30: 123131

3. Ratzmann KP, Gorr K, Schneider H (1994) Prävalenz diabetesbedingter Erblindungen. Eine Populationsstudie an 70203 Diabetikern. Diab Stoffw 3: 261-264

4. Young MJ, Boulton AJM, Macleod AF, Williams DRR, Sonksen PH (1993) A multicentre study of the prevalence of diabetic peripheral neuropathy in the United Kingdom hospital clinic population. Diabetologia 36 : $150-154$

5. The United States Renal Data System. USRDS 1994 Annual Data Report (1994) The National Institutes of Health, National Institute of Diabetes and Digestive and Kidney Diseases. MD

6. The Diabetes Control and Complications Trial Research Group (1993) The effect of intensive treatment of diabetes on the development and progression of long-term complications in insulin-dependent diabetes mellitus. $\mathrm{N}$ Engl J Med 329: 977-986

7. Reichard P, Nilsson BY, Rosenqvist U (1993) The effect of long-term intensified insulin treatment on the development of microvascular complications of diabetes mellitus. N Engl J Med 329: 304-309

8. UK Prospective Diabetes Study Group (1995) U.K. prospective diabetes study 16 . Overview of 6 years' therapy of type II diabetes: a progressive disease. Diabetes 44: 12491258

9. Turner R, Cull C, Holman R for the United Kingdom Prospective Diabetes Study Group (1996) United Kingdom Prospective Diabetes Study 17: A 9-year update of a randomized, controlled trial on the effect of improved metabolic control on complications in non-insulin-dependent diabetes mellitus. Ann Intern Med 124: 136-145

10. Ohkubo Y, Kishikawa H, Araki E et al. (1995) Intensive insulin therapy prevents the progression of diabetic microvascular complications in Japanese patients with non-insulin-dependent diabetes mellitus: a randomized prospective 6-year study. Diab Res Clin Pract 28: 103-117

11. Gries FA, Piwernetz K (eds) (1994) St. Vincent Register 1994. Beiträge zur Umsetzung der St.-Vincent-Deklaration in Deutschland. Verlag Kirchheim, Mainz, Germany

12. King H, Gruber W, Lander T (eds) (1995) Report of a WHO meeting. Implementing national diabetes programmes. WHO Division of Noncommunicable Diseases. Geneva

13. St. Vincent Group (1990) Diabetes care and research in Europe. The St. Vincent Declaration. Diabet Med 7: 360

14. Müller UA, Ross IS, Klinger H, Geisenheimer S, Chantelau EA (1993) Quality of centralized diabetes care: a population-based study in the German Democratic Republic 1989-1990. Acta Diabetol 30: 166-172

15. Schulz B, Bibergeil H, Rybka J, Koev D (1988) Strategy and structure of diabetes health care in some European Socialist countries. In: Krall LP (ed) World book of diabetes in practice. Elsevier, Amsterdam 3: 375-376

16. Müller UA, Müller R, Meier F (1995) Inzidenz von Ketoazidosen bei Diabetes mellitus unter zentralisierter und dezentralisierter Diabetesbetreuung in Thüringen. Diab Stoffw 4: 71-76

17. Jackson JL (1997) The German health system. Lessons for reform in the United States. Arch Int Med 157: 155-160

18. World Health Organization (1985) Diabetes mellitus. Technical reports series 727 . WHO, Geneva

19. Bruns W (1989) Behandlung mit Diät. In: Bibergeil H (ed) Diabetes mellitus. VEB Gustav Fischer Verlag, Jena, pp 254-315 
20. Mehnert H (1994) Ernährungstherapie. In: Mehnert H, Schöffling K, Standl E, Usadel KH (eds) Diabetologie in Klinik und Praxis. Georg Thieme Verlag Stuttgart, pp 162210

21. Chantelau E (1995) Diät (?) bei Diabetes mellitus. In: Berger M (ed) Diabetes mellitus. Urban und Schwarzenberg Verlag, Munich, pp 126-158

22. Scholz V, Grüßer M, Bott U, Jörgens V (1997) Behandlungs- und Schulungsprogramm für Typ-I-Diabetiker. Verlag Kirchheim, Mainz

23. Berger M, Bott U, Grüßer M et al. (1990) Behandlungsund Schulungsprogramm für Typ-II-Diabetiker, die Insulin spritzen. Deutscher Ärzte-Verlag, Cologne

24. Mühlhauser I, Jörgens V, Berger M (1983) Bicentric evaluation of a teaching programme for type I diabetic patients. Diabetologia 25: 470-476

25. Mühlhauser I, Bruckner I, Berger M et al. (1987) Evaluation of an intensified insulin treatment and teaching programme as routine management of type 1 (insulin-dependent) diabetes. The Bucharest-Düsseldorf Study. Diabetologia 30: 681-690

26. Müller UA, Hunger-Dathe W, Kobes M, Reuber E, Kirchner D (1995) Qualität der Stoffwechseleinstellung bei TypI-Diabetikern ein Jahr nach Teilnahme an einem strukturierten Behandlungsprogramm für intensivierte konventionelle Insulintherapie. Diab Stoffw 4: 9-13

27. Schiel R, Müller UA, Kalbas B, Franke I (1996) Diabeteswissen und Lebensqualität zweier Patientengruppen mit intensivierter konventioneller Insulintherapie. Vier Jahre bzw. unmittelbar nach Teilnahme an einem strukturierten 5-Tage-Behandlungsprogramm. Diab Stoffw 5: 63-68

28. Assal JP, Mühlhauser I, Pernet A, Gfeller R, Jörgens V, Berger M (1985) Patient education as the basis for diabetes care in clinical practice and research. Diabetologia 28: 602613

29. Berger M, Grüßer M, Jörgens V et al. (1987) Diabetesbehandlung in der Praxis: Behandlungs- und Schulungsprogramm für Typ-II-Diabetiker, die nicht Insulin spritzen. Deutscher Ärzte-Verlag, Cologne

30. Kohner E, Porta M (1992) Screening for diabetic retinopathy in Europe: a field guide book. WHO Regional Office for Europe, Kopenhagen

31. Liniger C, Albeanu A, Bloise D, Assal JPh (1990) The tuning fork revisited. Diabet Med 7: 859-864

32. Walters DP, Gatling W, Houston AC, Mullee MA, Julious SA, Hill RD (1994) Mortality in diabetic subjects: An eleven-year follow-up of a community-based population. Diabet Med 11: 968-973

33. Muggeo M, Verlato G, Bonora E et al. (1995) The Verona diabetes study: a population-based survey on known diabetes mellitus prevalence and 5-year all-cause mortality. Diabetologia 38: 318-325

34. Berger M, Jörgens V, Flatten G (1996) Health care for persons with non-insulin-dependent diabetes mellitus. The German experience. Ann Intern Med 124: 153-155

35. Ratzmann KP (1991) Eine Analyse von alters- und geschlechts-spezifischer Diabetesprävalenz sowie Behandlungsart: Die Berlin-Studie. Akt Endokrin Stoffw 12: 220223

36. Bibergeil H (1989) Diabetiker-Dispensairebetreuung. In: Biberbeil H (ed) Diabetes mellitus. VEB Gustav Fischer Verlag Jena, pp 669-673

37. Starostina EG, Antsiferov M, Galstyan GR et al. (1994) Effectiveness and cost-benefit analysis of intensive treatment and teaching programmes for type 1 (insulin-dependent) diabetes mellitus in Moscow - blood glucose versus urine glucose self-monitoring. Diabetologia 32: 170-176
38. Vaccaro O, Imperatore G, Ferrara A, Palombino R, Riccardi G (1992) Epidemiology of diabetes mellitus in Southern Italy: a case-finding method based on drug prescription. J Clin Epidemiol 45: 835-839

39. Bruno G, Bargero G, Vuolo A, Pisu E, Pagano G (1992) A population-based prevalence survey of known diabetes mellitus in northern Italy based upon multiple independent sources of ascertainment. Diabetologia 35: 851-856

40. Grüßer M, Jörgens V (1992) Diabetes in der Praxis. Fortbildungsveranstaltung „Diabetes mellitus“ für Kassenärzte. Projekt des Bundesministeriums für Gesundheit und des Zentralinstitutes für kassenärztliche Versorgung in der Bundesrepublik Deutschland in Zusammenarbeit mit der Deutschen Diabetesgesellschaft e. V., der Kassenärztlichen Bundesvereinigung und den Kassenärztlichen Vereinigungen der Länder. Deutscher Ärzteverlag Köln

41. Müller UA, Janz H, Rauchfuß J et al. (1994) Behandlungsqualität von Typ-II-Diabetikern 2 Jahre nach Umstellung auf Insulin und Teilnahme an einem strukturierten Schulungsprogramm im Vergleich zu herkömmlicher Instruktion im Krankenhaus. Diab Stoffw 3: 116 (Abstract)

42. Kronsbein P, Mühlhauser I, Venhaus A, Jörgens V, Scholz V, Berger M (1988) Evaluation of a structured treatment and teaching programme on non-insulin-dependent diabetes. Lancet 1407-1411

43. Jörgens V, Grüßer M, Bott U, Mühlhauser I, Berger M (1993) Effective and safe translation of intensified insulin therapy to general internal medicine departments. Diabetologia 36: 99-105

44. Pieber TR, Holler A, Siebenhofer A et al. (1995) Evaluation of a structured teaching and treatment programme for type 2 diabetes in general practice in a rural area of Austria. Diabet Med 12: 349-354

45. Müller UA, Reinauer KM, Voss $M$ and German Working Group for structured diabetes care (ASD) of the German Diabetes Association (1996) Continuous quality management of structured treatment and teaching programmes for type 1 diabetes on the national level in Germany. Diabetologia 39: A29 (Abstract)

46. Krans HMJ, Porta M, Keen H, Staehr Johansen K (eds) (1995) Diabetes care and research in Europe: the St. Vincent Declaration action programme. Implementation document. G Ital Diab 15: 1-84

47. Alberti KGMM, Gries FA (1988) Management of non-insulin-dependent diabetes mellitus in Europe: A consensus view. Diabet Med 5: 275-281

48. Alberti KGMM, Gries FA, Jervell J, Krans HMJ for the European NIDDM Policy Group (1994) A desktop guide for the management of non-insulin-dependent diabetes mellitus (NIDDM): An update. Diabet Med 11: 899-909

49. Berger M, Mühlhauser I (1995) Implementation of intensified insulin therapy: a European perspective. Diabet Med 12: 201-208

50. Müller UA, Janz H, Rauchfuß J et al. (1994) Behandlungsqualität von Typ-II-Diabetikern 2 Jahre nach Umstellung auf Insulin und Teilnahme an einem strukturierten Schulungsprogramm im Vergleich zu herkömmlicher Instruktion im Krankenhaus. Diab Stoffw 3: 116 (Abstract)

51. Müller UA, Mertes B, Hunger-Dathe W et al. (1994) Intensivierte Insulintherapie bei jüngeren Typ-II-DiabetikernBehandlungsqualität $1 \mathrm{Jahr}$ nach Teilnahme an einem strukturierten 5-Tage-Behandlungs- und Schulungsprogramm. Diab Stoffw 3: 170 (Abstract)

52. Schiel R, Müller UA, Ulbrich S (1997) Long-term efficacy of a 5-day structured teaching and treatment programme for intensified conventional insulin therapy and risk for severe hypoglycemia. Diab Res Clin Pract 35: 41-48 
53. Editorial (1992) Unsicherheit zum Jahresende. Diabetes Journal 41: 2

54. Mühlhauser I, Sulzer M, Berger M (1992) Quality assessment of diabetes care according to the recommendations of the St. Vincent Declaration: a population-based study in a rural area of Austria. Diabetologia 35: 429-435

55. Walters DP, Gatling W, Mullee MA, Hill RD (1992) The prevalence of diabetic distal sensory neuropathy in an English community. Diabet Med 9: 349-353

56. Ziegler D, Gries FA (1992) Epidemiologie der peripheren diabetischen Neuropathie. Diab Stoffw 2: 24-28

57. Amthor KF, Dahl-Jörgensen K, Berg TJ et al. (1994) The effect of 8 years strict glycemic control on peripheral nerve function in IDDM patients: the Oslo study. Diabetologia 37: $579-584$

58. Andersen AR, Christiansen JS, Andersen JK, Kreiner S, Deckert $T$ (1983) Diabetic nephropathy in type 1 (insulin dependent) diabetes: an epidemiological study. Diabetologia 25: 496-501
59. Ballard DJ, Humphrey LL, Melton LJ et al. (1988) Epidemiology of persistent proteinuria in type II diabetes mellitus: population-based study in Rochester, Minnesota. Diabetes 37: $405-412$

60. Mühlhauser I, Sawicki P, Berger M (1986) Cigarette smoking as a risk factor for macroproteinuria and proliferative retinopathy in type 1 (insulin-dependent) diabetes. Diabetologia 29: 500-502

61. Couper JJ, Staples AJ, Cocciolone R, Nairn J, Badcock N, Henning P (1994) Relationship of smoking in children with insulin-dependent diabetes. Diabet Med 11: 666-669

62. Mühlhauser I (1995) Effizienznachweis und Qualitätskontrolle. In: Berger $\mathbf{M}$ (ed) Diabetes mellitus. Urban und Schwarzenberg Verlag, Munich, pp 309-316

63. Brook RH, McGlynn EA, Cleary PD (1996) Measuring quality of care. (Quality of health care, Part 2). N Engl J Med 335: 966-970 